\title{
Tomasz Jeż: Danielis Sartorii Musicalia Wratislaviensia (= Fontes musicæ in Polonia, A/I)
}

Warszawa : Wydawnictwo Naukowe Sub Lupa, 2017. ISBN: 978-83-65886-11-8

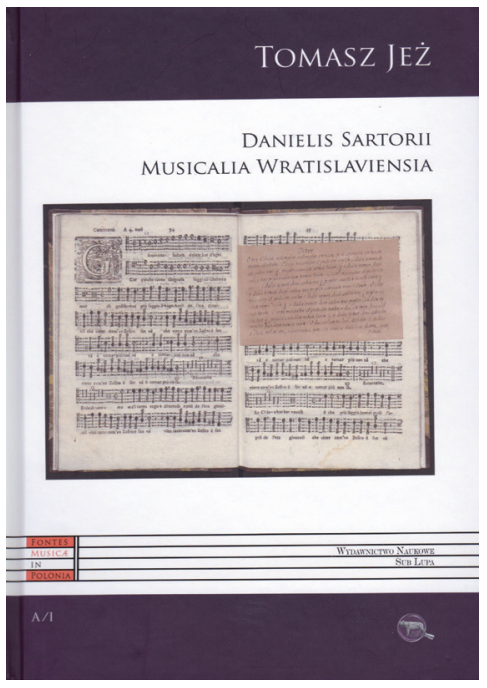

Projekt Fontes musica in Polonia vznikol pod gesciou Katedry dejín polskej hudby Inštitútu muzikológie Varšavskej univerzity (Zakład Historii Muzyki Polskiej, Instytut Muzykologii, Uniwersytet Warszawski) v roku 2016 a za uplynulé štyri roky v ňom vyšlo 28 publikácií, ktoré prinášajú edície historických hudobných prameňov zachovaných na území dnešného Pol’ska. Projekt je rozdelený do troch sérií podla typu vydávaných prameňov: sériu $A$ tvoria edície inventárov hudobnín, resp. katalógy zbierok hudobnín zachovaných $\mathrm{v}$ Pol'sku, $\mathrm{v}$ tejto sérii doteraz vyšli štyri publikácie, zodpovední redaktori série A sú Tomasz Jeż a Katarzyna Spurgjasz; sériu $B$ tvoria knihy o hudbe, ktoré prinášajú faksimilové edície a vedecké práce $\mathrm{k}$ dejinám hudby, v tejto sérii doteraz vyšlo pät kníh, zodpovední redaktori série $B$ sú Tomasz Jeż a Bogna Bohdanowicz; sériu $C$ tvoria kritické edície hudobných notovaných prameňov, $\mathrm{v}$ tejto sérii doteraz vyšlo devätnást publikácií, zodpovední redaktori série $C$ sú Tomasz Jeż a Maciej Jochymczyk. Projekt Fontes mu- sicae in Polonia je financovaný Ministerstvom vedy a vyššieho školstva (Ministra Nauki i Szkolnictwa Wyższego) v rámci programu Tradície - Národný program rozvoja humanitných vied (Narodowy Program Rozwoju Humanistyki).

Ako prvá publikácia v sérii $A$ vyšla kniha Danielis Sartorii Musicalia Wratislaviensia Tomasza Jeża, ktorá vznikla v rámci individuálneho projektu Repertuar muzyczny kościołów i klasztorów Śląska w czasach nowożytnych [Hudobný repertoár kostolov a kláštorov Sliezska v ranom novoveku]. Kniha je koncipovaná ako vedecká monografia predstavujúca unikátnu Zbierku hudobnín Daniela Sartoria, ktorú kolektor zhromaždil pre potreby hudobného života evanjelického luteránskeho Kostola sv. Alžbety, a tiež známeho gymnázia Elisabetanum v 17. storočí. Predmetom publikácie je komplexná charakteristika genézy a osudov Zbierky hudobnín Daniela Sartoria, začlenenie zbierky a jej tvorcu do dejín hudobnej kultúry mesta Vroclav (hist. Breslau), opis a analýza obsahu zbierky hudobnín (katalóg), charakteristika tezaurovanej hudby a zhodnotenie význa$\mathrm{mu}$ hudobnín $\mathrm{v}$ globálnom, nadeurópskom meradle. Napriek tomu, že k obsahu zbierky hudobnín bolo vytvorených niekolko čiastkových katalógov, doteraz nebola predmetom komplexného monografického spracovania. Spôsobili to nielen pohnuté osudy zbierky - hudobniny sa viackrát stahovali za rôznych, i vojnových okolností, ale aj rozsah zbierky - ide totiž o početný súbor prameňov, ktorý v súčasnosti pozostáva z 399 hudobných tlačí publikovaných v rokoch 1606 - 1665 a piatich rukopisov $\mathrm{z}$ toho istého obdobia. Tieto hudobniny uchovávajú objemný hudobný repertoár, ktorý tvorí viac ako 8000 skladieb. Navyše ide o svetovo unikátnu zbierku starých talianskych tlačí.

Zbierka hudobnín Daniela Sartoria vznikla ako osobný fond profesora vroclav- 
ského luteránskeho gymnázia pri Kostole sv. Alžbety Daniela Sartoria (1612 - 1671). Po jeho smrti sa stala súčastou bohatej súkromnej knižnej a muzeálnej zbierky vroclavského meštana Thomasa Rehdigera (1540 - 1576), ktorá neskôr dostala názov podla svojho zakladatela Bibliotheca Rhedigeriana. V rokoch 1589 - 1645 sa nachádzala $\mathrm{v}$ jednej z miestností Kostola sv. Alžbety (Elisabethkirche). V roku 1645 bola oficiálne darovaná mestu Vroclav a stala sa prvou verejnou mestskou knižnicou. V rámci týchto premien boli tlače a rukopisy zo Zbierky hudobnín Daniela Sartoria k dispozícii praktickým potrebám hudobného života v gymnáziu i kostole. Osobitne môžeme sledovat ich prepojenie s pôsobením Ambrosia Profia (1589 - 1661), odchovanca Alžbetínskeho gymnázia, neskoršieho tamojšieho profesora a organistu v Kostole sv. Alžbety, známeho vydavatela talianskej hudby v Sliezsku. Zbierka hudobnín Daniela Sartoria - dopíňaná Profiovými aktivitami - sa zachovala $\mathrm{v}$ ucelenom fonde až do druhej polovice 19. storočia, ked' ju začlenili ako čast' zbierkového fondu Bibliotheca Rhedigeriana do novozaloženej Vroclavskej mestskej knižnice (Stadtbibliothek zu Breslau, 1865 - 1867). Tu sa tematicky zjednotili muzikálie s ostatnými zbierkami hudobnín a celkový obsah takto vzniknutej rozsiahlej zbierky hudobnín poznajú súčasní muzikológovia prostredníctvom dvoch katalógov Emila Bohna (1839 - 1909), knihovníka bývalého vroclavského Královského akademického Inštitútu pre cirkevnú hudbu (Das Königliche Akademische Institut für Kirchenmusik). Emil Bohn v dvoch katalógoch osobitne evidoval hudobné rukopisy (1883) a hudobné tlače
(1890). ${ }^{1} \mathrm{~V}$ stredoeurópskej hudobnej historiografii je však málo známy fakt, že ešte pred samotným zjednotením muzikálií v bývalej Vroclavskej mestskej knižnici ${ }^{2}$ vzniklo niekol'ko cenných predmetných katalógov jednotlivých fondov Rehdigerovej knižnice, ktoré vypracoval Siegfried Wilhelm Dehn (1799 - 1858), kustód hudobných zbierok Královskej knižnice v Berlíne. Medzi nimi sa nachádza aj čiastkový inventár hudobnín Catalogus der auf der Elisabeth-Bibliothek befindlichen Musicalien (Rhedigerische Bibliothek) z roku 1853, ktorý poslúžil autorovi publikácie Danielis Sartorii Musicalia Wratislaviensia Tomaszovi Jeżovi ako východisková báza na usporiadanie a skatalogizovanie Zbierky hudobnín Daniela Sartoria.

Publikácia je zostavená ako vedecká monografia v dvoch častiach: prvú tvorí rozsiahla úvodná štúdia v pol'skej a anglickej verzii, druhú tvorí samotný katalóg hudobnín. Úvodná štúdia predstavuje syntetické spracovanie problematiky, rozdelené do dvoch kapitol: v prvej kapitole je predstavená história zbierky a jej osudy, druhá kapitola sa venuje hudobnému repertoáru. Čitatela zaujmú už samotné osudy vroclavských muzikálií zo Zbierky hudobnín Daniela Sartoria, ktoré boli počas II. svetovej vojny rozdelené na skupiny a skryté v menších obciach Dolného Sliezska mimo mesta Vroclav, čím ich zachránili pred úplným zničením počas bombardovania centra mesta. Z týchto skrýš boli tesne pred koncom vojny odvezené do Moskvy a odtial' (väčšina z nich) do Berlína, do bývalej Štátnej knižnice pruského kultúrneho dedičstva (Musikabteilung Preußischer Kulturbesitz Staatsbibliothek zu Berlin). Autor publikácie uvádza, že spomedzi hudobných tlačí preži-

1 Bibliographie der Musik-Druckwerke bis 1700 welche in der Stadtbibliothek, der Bibliothek des Akademischen Instituts für Kirchenmusik und in der Königlichen- und Universitätsbibliothek zu Breslau aufbewahrt werden. Ed. Emil Bohn. Berlin : A. Cohn, 1883. Die musikalischen Handschriften des XVI. und XVII. Jahrhunderts in der Stadtbibliothek zu Breslau. Ed. Emil Bohn. Breslau : Hainauer, 1890.

2 V roku 1889 boli do Vroclavu (Breslau) deponované hudobné pramene zo Zbierky královského gymnázia v Brehu (Brieg), hudobniny Georga Rudolpha, kniežata v Legnici (Liegnitz) a d’alšie muzikálie. KOLBUSZEWSKA, Aniela: Historische Grundlagen der Musiksammlungen in der Universitätsbibliothek zu Breslau (= Deutsche Musik in Osten, 6). Eds. Klaus Wolfgang Niemöller, Helmut Loos, Bonn : Gudrun Schröder Verlag, 1994, s. 295-302. 
lo vojnové kataklizmy okolo $70 \%$ jednotiek a tie boli v roku 1946 prevezené do Univerzitnej knižnice vo Vroclavi (Biblioteka Uniwersitetu Wrocławskiego). Vroclavské hudobniny - a to nielen tlače, ale aj pôvodné rukopisy - vzbudzovali celé desatročia velký záujem muzikológov a hudobníkov pôsobiacich v mnohých krajinách, pretože ich depozit v Berlínskej knižnici bol až do roku 1989 utajený. Niekol'ko z nich sa dodnes nachádza v Moskve. ${ }^{3}$

Pri charakteristike hudobného repertoáru, ktorý obsahujú katalogizované muzikálie, sa autor knihy Tomasz Jeż ukazuje ako vynikajúci znalec polsko-talianskych hudobných kontaktov v ranom novoveku. Špecifikom zbierky je totiž takmer výlučná orientácia na talianske hudobné tlače. Až 90 \% jednotiek tvoria staré tlače benátskych oficín Alessandra a Giacoma Vincentiovcov alebo Bartolomea a Francesca Magniovcov. Ide o klúčové benátske tlačiarne, ktoré produkovali najvýznamnejšiu taliansku hudbu, hlavne repertoáru seconda pratica. Zvyšných 10 \% tvoria tlače, publikované v Taliansku (Bologna, Florencia, Rím, Neapol) a v nemeckých mestách (Dráždany, Frankfurt nad Mohanom, Freiberg, Ingolstadt, Lipsko, Ravensburg, Innsbruck). Mnohé tlače patria k typu autorských tlačí, obsahujúcich skladby len jedného skladatela; najviac sú zastúpené tlače Alessandra Grandiho, maestra di cappella v benátskej Bazilike San Marco a v kostole Santa Maria Maggiore v Bergame. Celkovo reprezentuje repertoár tlačí diela až 165 skladatelov. Z nich okolo 95\% tvorí hudba talianskych skladatelov; zvyšných $5 \%$ tvorí hudba nemeckých autorov, ktorí patrili v tom čase k znalcom talianskeho štýlu komponovania (Ph. F. Buchner, J. Rosenmüller, J. H. Schein, H. Schütz, Ch. Waesich). Druhá čast' knihy - samotný katalóg hudobnín - poskytuje metodologicky moderne spracovaný opis jednotlivých tlačí, s identifikáciou autora a vy- davatela, so zaradením do katalógu RISM, $s$ diplomatickou transkripciou hudobného repertoáru a bibliografickými odkazmi na kritickú edíciu, digitalizáciu prameňov, resp. profesionálne nahrávky hudobného repertoáru. Kniha obsahuje všetky typy registrov (menné, miestne, skratky, vysvetlivky, literatúru, pramene), ktoré sú v takýchto objemných textoch obzvlášt užitočné.

Autor publikácie Danielis Sartorii Musicalia Wratislaviensia profesor Varšavskej univerzity Tomasz Jeż spracoval $\mathrm{v}$ tomto prvom zväzku série A edície Fontes musica in Polonia na profesionálnej úrovni závažnú problematiku katalogizácie hudobných prameňov. Vo svojej práci čerpá zo svojich dlhoročných skúseností a vlastného heuristického výskumu prameňov v celoeurópskom meradle, vrátane archívnych výskumov v Taliansku. Hodnotu publikácie zvyšuje spojenie monografického spracovania problematiky a katalógovej databázy prameňov; tým sa kniha bezpochyby stane stimulom na d’alší výskum dejín hudobnej kultúry Sliezska a špeciálne recepcie talianskeho dedičstva Seicenta v strednej Európe. Muzikológovia zároveň dostali $\mathrm{k}$ dispozícii d’alší katalóg starých tlačí zachovaných na území súčasného Pol'ska, čím sa práca priradí k doterajším početným pol’ským publikáciám takéhoto typu; za všetky spomeňme aspoň Catalogue of Early Music Prints from the Collections of the Former Preußische Staatsbibliothek in Berlin, Kept at the Jagiellonian Library in Cracow (1999) - katalóg Aleksandry Patalas, ktorá spracovala databázu starých tlačí z fondov bývalej Štátnej knižnice pruského kultúrneho dedičstva $\mathrm{v}$ Berlíne, uložených v súčasnosti v Knižnici Jagelovskej univerzity v Krakove. ${ }^{4}$ Vdaka týmto katalógom nadobúda problematika migrácie hudobnín v stredoeurópskom a celoeurópskom priestore nové, presnejšie kontúry.

\footnotetext{
Moskva, Rossijskij nacionalnyj muzej muzyki (RUS-Mcm).

4 PATALAS, Alexandra: Catalogue of Early Music Prints from the Collections of the Former Preußische Staatsbibliothek in Berlin, Kept at the Jagiellonian Library in Cracow / Katalog starodruków muzycznych z XVI i XVII w. ze zbiorów byłej Pruskiej Biblioteki Państwowej w Berlinie, przechowywanych $w$ Bibliotece Jagiellońskiej w Krakowie. Kraków : Musica Iagellonica, 1999.
} 
Všetky publikácie vydávané $\mathrm{v}$ projekte Inštitútu muzikológie Varšavskej univerzity Fontes musica in Polonia vychádzajú v tlačenej verzii a dostupné sú aj online na webovej stránke http://fontesmusicae.pl/ fontes-pl/. V krátkom čase niekolkých rokov sa tento projekt Varšavskej univerzity zara- dil medzi najväčšie polské projekty vydávania hudobných prameňov $\mathrm{z}$ historického územia bývalého štátneho útvaru Republika oboch národov (Rzeczpospolita Obojga Narodów). ${ }^{5}$

Janka Petőczová

\section{Jozef Sixta: Portrét skladatela}

Ed. Peter Javorka. Bratislava : Hudobné centrum, 2020, 291 s. ISBN 978-80-89427-66-6

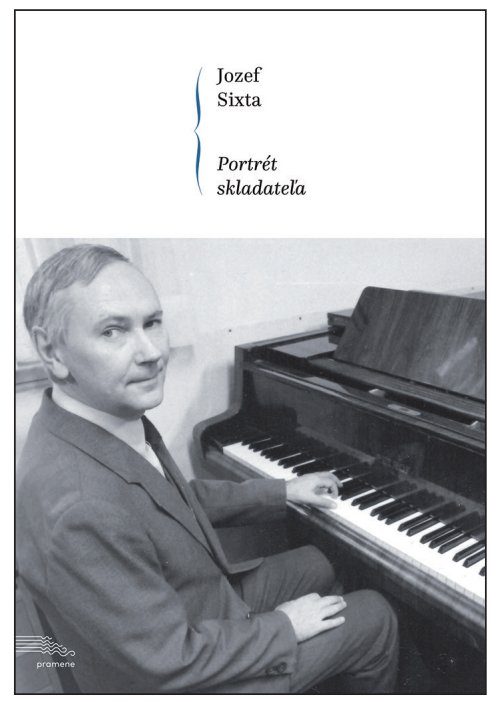

Edičné oddelenie Hudobného centra sa snaží každoročne rozšírit svoje portfólio knižných monografií o práce o slovenských skladateloch či osobnostiach slovenskej hudobnej kultúry. V niektorých prípadoch ide o reedície teoretických diel skladatelov (I. Hrušovský: Úvod do štúdia teórie harmónie, 2019; E. Suchoň: Hudobnoteoretické dielo, 2018), v iných zas o sumarizáciu autorských textov, rozhovorov a textov teoretikov o významných skladatel’och, čím vznikajú biografické a analytické monografie (I. Parík: Fragmenty a úvahy, 2017; I. Zeljenka: Rozhovory a texty, 2018). Kniha Jozef Sixta: Portrét skladatel'a patrí práve do druhej kategórie publikácií, ktoré Hudobné centrum vydáva ako edíciu s označením „Pramene“.

Mladý skladatel' a editor monografie Peter Javorka zostavil knihu jednak z textov, ktoré vznikli v priebehu Sixtovho života a boli už publikované v hudobných periodikách $(\mathrm{Hu}$ dobný život, Slovenská hudba, Slovo, Tempo), konferenčných zborníkoch (Prezentácie - konfrontácie, Zborník z medzinárodného sympózia v rámci festivalu Melos-Étos) alebo monografiách (L. Chalupka: Slovenská hudobná avantgarda, Generačné a štýlové konfrontácie. Sprievodca slovenskou hudbou 20. storočia II. (1950 - 2000)). K tomu pridal texty, ktoré ešte neboli publikované a vznikli pri príležitosti vydania tejto publikácie, resp. sa našli v Sixtovej pozostalosti ako doteraz nezverejnené. Cielom editora P. Javorku bolo zhromaždit’ všetky závažnejšie texty o Jozefovi Sixtovi a jeho hudbe a vydat ich ako jedno súborné dielo napriek tomu, že vel'ká

$5 \quad$ V pol'skej muzikológii je d’alším takýmto projektom edícia Monumenta Musicae in Polonia, ktorú zastrešuje Oddelenie hudobnej histórie Ústavu hudobnej vedy Umenovedného inštitútu Pol’skej akadémie vied (Zakład Muzykologii, Pracownia Historii Muzyki, Instytut Sztuki Polskiej Akademii Nauk). 